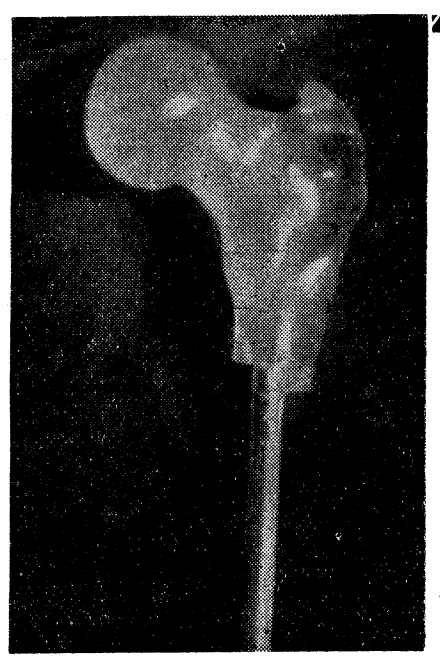

高分子と整形外科

整形外科領域に特いてはいろいろな方面で高分子製品 が使われて物り，また研究されている。高分子自身に対 しては私達は素人であるので，ここには單にその內容の 紹介にとどめ, また私達の希望も述べて㫮樣の御援助を 得たいと思う。

\section{1. 体の中への碓用}

\section{a. 骨の代用}

癌とか肉腫などが骨に生じた場合はなるべく早くその 手足を切断して，生命を救打うとするのが通例である。 しかしその惡性度がそれ萎ど激しくなく，その惡い骨だ けを剔出除去すれば必ずしもその手足自身を全部切断し なくてもよい場合がないでもない。その場合その骨の欠 損を代用するのにアクリル酸樹脂か現在用いられてい る。

写嗔 1 は大腿骨の上端を惡性腫瘍で剔出された 52 才 の男の方にしたもので, 患者されと同じ大きさの大腿骨 多多くの屍体の骨のなかから探し出し, それを原型とし てギプスで陰性モデルをつくるのである。芯棒には $22 \mathrm{~A}$ 鋼といって体內でも絕対に 腐蝕されない特殊鋼を埋め こんである。写顓 2 はその レ線写自で，芯の $22 \mathrm{~A}$ 鋼 のみか濃く写っている。こ の鋼芯を切断した大腿骨の 遠端の骨髓のなかに打ち达 むのである。この人は手術 後の経過が良好で, 牛年後 には杖をついて自宅附近を 1 籸位步くことができるよ うになった。

写傎 3 ほ前の患者のごと き惡性腫癔とは異り, 股関 節の疼痛を主な症候とする

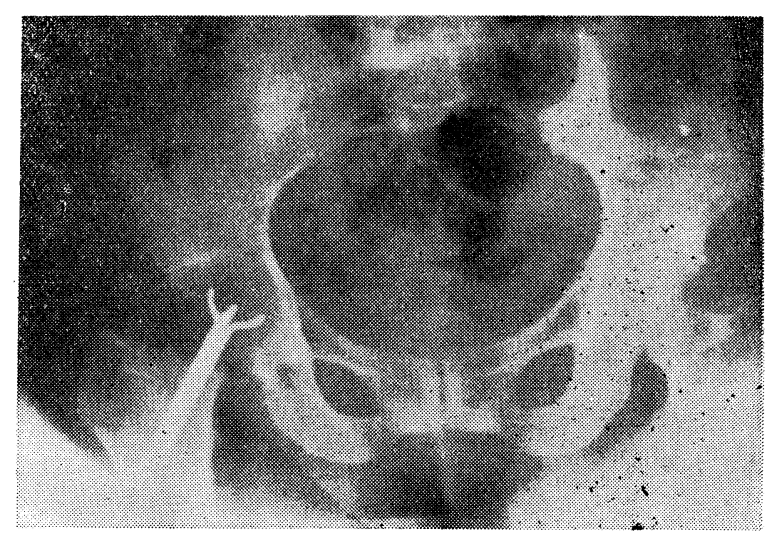

写覓 3. 右变形性股関節症で股関節の疼痛の强い患者に, 大腿骨の上端をアクリル酸樹脂による人工代用骨に置換 したるの
写眞 2.

写眞 1 のレ線像荵 の22A 鋼のみがけ つきりでている

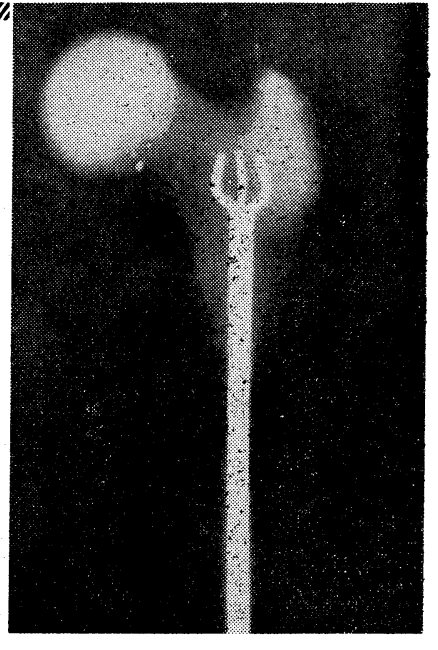

変形性関節症の万に，大腿骨の上端をわざわざアクリル 酸樹脂の骨頭に括き換えたもので，これは後に述べる Judet 型を用いたるののレ線写自である。ここでは蒖の $22 \mathrm{~A}$ 鋼のみが写っていることは写傎 1,2 と同樣である。

\section{b. 関節の癒著の防止としての利用}

関節炎などのために関㹂が癒著して動かすことができ なくなった患者さんに, 手術をして再び動かせるように するのを関節授動術という。この際，手術をして新しい 関節をつくるのであるが，関節をはさむ上下の骨端をそ のままにしておいたのでは早晚再び癒著して関節ま再び 動かなくなってしまう。そこでその癒著を防止する中間 插入膜または中間搟入帽が使用せられる。これには数カ 月後には吸收される吸收性插入物と，永久に吸收されな い非吸收性插入物の 2 種があり，それぞれの使用目的が ある。吸收性插入物としてはその患者の大腿部から探取 した筋膜，それをクローム処理して体內での吸收を遅ら せたもの，その材料を屍体の筋膜から探るもの，さらに 馬の腸とか牛, 胍の膀胱などが使用せられる。次に非吸 收性物質としてはナイロン 膜, ビニル膜和よびアクリ ル酸樹脂による骨頭帽など がある。

さて以上に述べた体內に 埋めこむ物質についての歴 史に少し触れてみよう。関 節の手術後の癒著を防止す る方法として 1877 年 Carnochan か䫈の関節强直に 対与る授動手術に木片を用 いたのをはじめとして，そ の後諸家によりアルミ二 一ム板, マグネシウム板, 銀板, 七ルロイド, グッタ 
ベルカ, 鉛板，ゴム膜，コロジウムなどが試みられたが， いずれも体內での刺㖪があるために異物として体外に排 出されたりして失敗に帰した。一方 1863 年 Verneuil は骨折の際，之の骨折部の両断端の間に自分の筋や筋膜 などがはさまっていると，その骨がつかないことにヒン 卜を得て，䇗膜や脂肪なぞを吸收性中間插入膜として使 用した。1918年 Baer は豚の膀胱膜をクローム硬化して 使用して，その体內での吸收速度を適宜に調節できるこ とを発見して好成績が得られるようになった。わが國で もこれに類するものに神中，河野両敉授による患者当人 の大腿筋膜をクローム処理した J K膜，奧田㸚授等によ る馬の腸などをクローム処理した OMS 膜なぞがある。

さらに骨折の際の骨の縫合物質として 1647 年に Fabricus は鉄線を用い，19 世紀になると金，銀，白金など の研究が進み，多く銀線が使用せられるようになった。 体內に使用する金属は腐蝕したり，電解したり，生体に 刺戟を與えてはいけないので，その目的に沿うた合金の 研究子進み, 1926 年 M. Lange は Kruppe 不銹鋼 V2A の優秀性を報告し，またアメリカでは S MO など の 18-8 不銹鋼が発達した。1934 年になるとコバルトを 主とし，鉄を含まないバイタリウムがあらわれ，その非 電解性などからして体內挿入金属としては最優秀のもの であるとされた。わが國でも東北大学の飯野, 今井両敎 授によるニッケルを $22 \%$ 含有した $22 \mathrm{~A}$ 鋼がバイタリ ウムに劣らない優秀品であることを発見し，現在わが國 で廣く使用せられている。

1939 年アメリカの Smith-Peterson は股関節の手術 の際に，大腿骨骨頭をバイタリウムの諠子を被せてその 再癒著を防ぎ, 好成績を挙げて以來, かかる手術が欧米 で盛んに行われた。しかしかかるバイタリウムも絕対に 生体に刺载を與えないというわけではなく，数年後には 再び临種の变化の生じて來た㭧者ひ決して少くないこと が漸次わかって來た。

一方フランスでは 1947 年に Virenque 等がアクリ

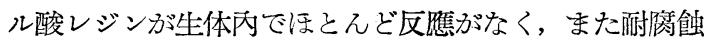
性などがすばらしいことを発表し，同じくフランスの Judet 兄弟飞動物实羷索経て, 人体の股関節の改造手術 に礁用して好成績を收めたことを1950 年発表した。こ の Judet の報告はた台ま台世界の視聽を集め, 各國で 追試されてその症例はすでに万を超すに至っているであ ろう。

さて現在わが國では一般にかかる代用骨はメタアクリ ルをポリマー〜モノマー法て製作されている。これはポ リマー法またはモノマー法によるるのに比してレジンと 乙ての物理的性質に劣っているので，著者の一人小林は 日本歯大秋山呚授と協同して, 低溫, 恒溫室內でモノマ 一を陰性モデル內に少量づつ重層して行く方法を考案し てほほぼモノマー法によるレジンの物理的性質に近いも
のを製作し得るに至っている。

なお PVA膜の龢化度を調節して体內で，一定期間後 吸收さ得るようにしたり，酸化七ルローズやアルギン 酸ソーダなどに関する研究もある。

\section{c. その他の体內での使用}

アメリカの交献で動物実驗のみであるが，大動脈の手 術の後に，そこを補强する目的でビニルスポンジのシー トで卷いて抢くと，そこに結合織が侵入してきて，固い 結合織の被膜ができると書いてある。

美容外科に属するが，鼻翼や耳の成形の際に，その部 にアクリル薄板を入れることがある。

ナイロンの系は大分使われるようになって來た。系自 身による刺戟がないのが特長である。

\section{2. 手術器械として}

整形外科の手術では, 手術中にレ線撮影や透視を要す る場合が多い。そこで手術台自身がその目的に邀うよう に設計されている。例えば透視を必要とする部分に鉄の 支杜がないように設計するとか，手術台の板をアクリル 板とするなどである。

手術のときの創口を開く鈎もアクリル酸樹脂なぞでつ くっていると透明で便利である。

手術のときの血を械うガーゼ代りにスポンジゴムがよ く使われるが,これにビニルスポンジを用いる人ぬある。

\section{3. ギプスの補强}

ギプスなくして整形外科なしといった人が岁る位に整 形外科にとってギプスは大切なりのである。しかしギプ スコルセットや手足に卷いたものはなにぶんにも重かっ たり，水に濡れるといたむという久点がある。そこでギ プスの强化法が考 えられている。

アメリカで出さ れているメルマッ クというのはメラ ニン樹脂で, 触媒 として塩化安門が 使われる。同樣な 補强材のフェノリ ックスはフェノー ル・レゾルシンレ ジンで和製のコン ソリジンは尿素系 樹脂である。

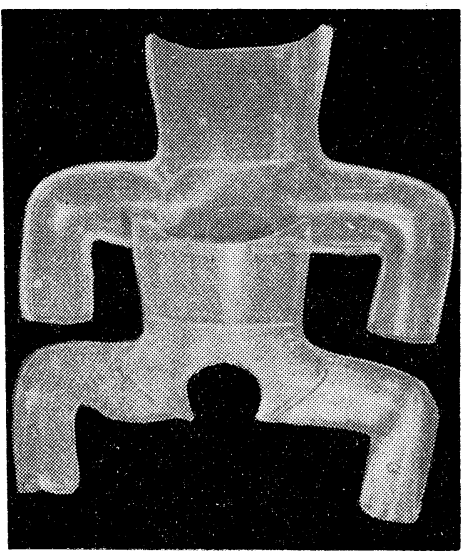

写覓 4. アゥリル酸樹脂による 先天性股関篩用裝具

\section{4. 義肢・裝具への應用}

写缶 4 は先天性股関笁脫曰の際の固定用裝具で, アク リル酸樹脂である。通常かかる裝具はギプスでりくられ るが，それでは患兒の小便で破壞される，重いなどの欠 


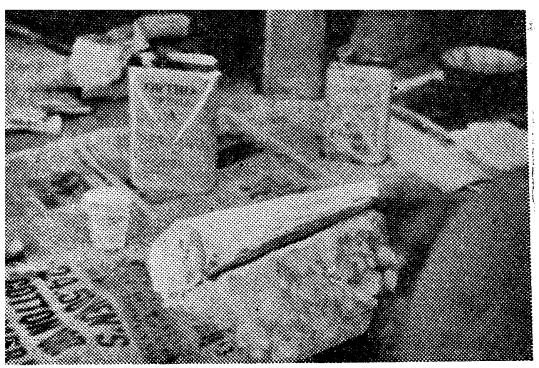

写自 5. ラミナックレジンで義肢をつく っているところ。ギプス雄型の团りを ガラスファイバーを惢としてオーソボ ンド 2 液を㙦りこんだところ

点がある。そこでセルロイド積層板とか, 合成樹脂でつ くられることがある。写产期ごとき为のでは軽く, 透明 で,かつそのまま風呂にも入れられるなどの利点がある。 同じ目的でせルロイドュルセットの代りにアクリル酸樹 脂でりくられることがあり，これであると透明で紫外線 を透す特長がある。しかしこれらの製品は既製の板を熱 してギプスの雄型に圧して成型するもので，表面が單純 なものにしかできないのと，またその彈性がセルロイド に劣る欠点加ある。

写筫 5,6 はラミナックレジンで義肢をつくっていると

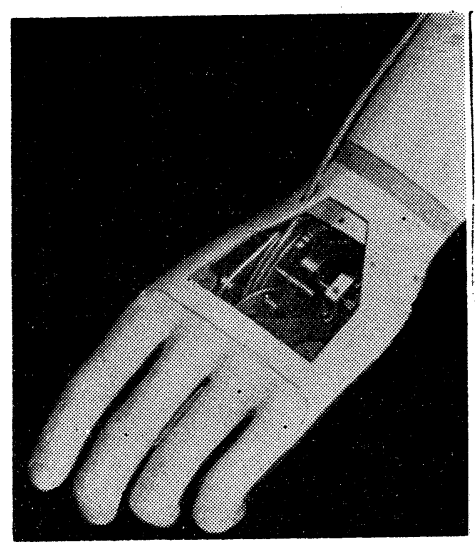

写畺 8. 樹脂製義手 ころである。これ には硬軟 2 凨があ り, 硬化用剂 60 $\%$, 柔軟用剂 $40 \%$ の割で混合して用 いる。写蒖 5 はべ ルノン会社のオー ソボンドの 2 液を ギプス雄型の表面 にガラスファイバ 一を芯として整り こんだところであ る。これを $180^{\circ} \mathrm{F}$ で 30 分閒炬の中で乾燥して硬化させた後に, 写覓 6 は 中のギプス型を金粗で㠲いて出したところである。この ようにポリエステルで製作されたるのは强勒である。

写鱼 7 は同樣に義肢をつくっているところであるが, ガラスファイバーにポリエステルを笙りこむ代りに，P VA膜で包み，片方をしばり，他方からポリエステルの

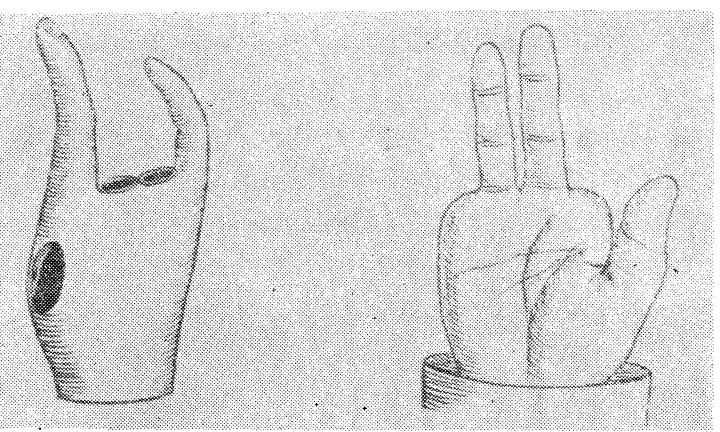

写锢 9. 人工皮膚の指, 右示指, 小指欠損者に対するもの
液を注入したもので，この方が製品が綺麗にできる。な 物写眞で見られるようにポリエステル筒に金属の金具を 埋めこもことができるので，金属支杜が不要となり非常 に軽くできあがる。

アメリカでセラスチックという副木がある。材料は厚 さ 2 ミリ位の板狀になった石綿の表面を滑かにしたよう なもので, それを水につけると柔軟になり,患者の手や指 に合せてモデリングしておき，ついでその板にセラスチ ック溶剤を塗ると硬化するのである。これは2枚を貼り合 せることや鋏で細工もできて非常に便利なるのである。 写覓 8 の義手は合成樹脂でっくって岁るが，之の資材は 何であるかちょっとわからない。わが國では現在義手の 指などは桐，アルミニュームなどでりくられているが， 樹脂の方が墸種の点で優れている。

写臭 9 は土の皮膚である。これはゴムラテックス やビニル系統のものでりくられるが，現在アメリカで製 作されているものは実によくできて扣り，柔かさ，色， 指紋など注交者の皮膚气のままにでき上っている。これ で義手の手袋をつくったり，写覓のごとく指の欠損者に 人工の指をつくり裝飾の目的を達している。

革のコーチングとして義肢の革を耐水性にするための 塗布液もアメリカで市販されているが，ナイロン細片 20 グラム,イソプロピルアルコール $170 \mathrm{cc}$, 水 $30 \mathrm{cc}$ の処 方で自分でもつくれる。

また義肢の接手の部分の接続に金属でなしにナイロン の紐をより合わせて使われたりしている。

\section{5. あとがき}

医療関係のものは一般にそうであるが，特にこの原稿 に紹介したような高分子製品は大量生產工業の対照とは ならない。代用骨を例にとると各症例ごとに型が異り， から処方されてから数日の中には遅くともできていなけ ればならない。したがって多くの敎室では自分の処で手 製しているのである。またアメリカで廣く行われている ポリエステルの義肢や裝具などの製作む，だれでもが簡 單にできるように，実に親切に气の材料が組及合わされ て販賣されている。わが國でも一日る早く欧米の線まで 材料の供給が円滑になることを切に願うものである。

(前山大学整形外科, 束京整肢源護園, 米关厚生年金 湯河原整形外科病院） 